\title{
Efficacy of Compatibility between Endophytic Biocontrol Agents and Abiotic Agents as Fungicides Alternatives for Controlling Root Rot of Grapevine
}

\author{
El-Sayed Hussein Ziedan ${ }^{*}$, Moataza Mahmoud Saad ${ }^{2}$, Mohamed \\ Abd-El-All El-Naggar ${ }^{1}$, Khames Ahmed Hemida ${ }^{1}$, Magdy Gad El-Rab El \\ Samman $^{3}$ and Mostafa Helmy Mostafa ${ }^{3}$ \\ ${ }^{1}$ Plant Pathology Department, National Research Centre, Cairo, Egypt \\ ${ }^{2}$ Microbial Chemistry Department, National Research Centre, Cairo, Egypt \\ ${ }^{3}$ Plant Pathology Department, Faculty of Agriculture, Ain Shams University, Cairo, \\ Egypt \\ *Corresponding Author: El-Sayed Hussein Ziedan, Plant Pathology Department, \\ National Research Centre, Cairo, Egypt. \\ Orcide Number: 0000-0003-1235-0318.
}

Received: February 25, 2020

Published: April 09, 2020

(C) All rights are reserved by El-Sayed

Hussein Ziedan., et al.

\begin{abstract}
Root rot of grapevine an epidemic disease causing by several soil borne fungi recorded high loss plant growth of productivity. Nine endophytic biocontrol fungal and bacterial isolates of Trichoderma spp, Bacillus spp and Pseudomonas fluorescens were tested against growth of aggressive fungal isolates causing root rot of grapevine i.e. Fusarium spp. and Botryodiplodia theobromae. Results showed that the best antagonistic endophytic isolates were Trichoderma harzianum and Bacillus subtilis. Trichoderma harzianum isolate significantly reduced mycelial linear growth and conidial sporulation of fungi tested as well as over lapping growth of fungi tested. In addition, Bacillus subtilis recorded high zone inhibition toward all pathogenic fungi tested than another bacterial isolates in this study. Some promising essential oils, organic, antioxidants acids and their combinations were tested on growth of endophytic biocontrol agents of Trichoderma harzianum and Bacillus subtilis. Results obtained indicated that sorbic acid followed by propionic acid were the least effect on mycelial linear growth and conidial sporulation of Trichoderma harzianum. In addition, sorbic acid, propionic acid $(0.1 \%)$, black seed oil (4.0\%) and their combination had no effect negatively on Bacillus subtilis growth. In greenhouse experiment soil drench by propionic + sorbic acids, propionic acid + sorbic acid + T. harzianum + B. subtilis were the best and significantly treatments its completely suppress (100\%) root rot disease percentage and disease severity on shoots and roots of grapevine plants followed by T. harzianum as individual or combination with B. subtilis were increased morphological characters of grapevine plant i.e. length, fresh and dry weight of and root size. So, combined soil treatment by propionic acid + sorbic acid or propionic acid + sorbic acid + T. harzianum + B. subtilis as the safe fungicide alternatives for management root rot disease of grapevine.
\end{abstract}

Keywords: Bacillus subtilis; Grapevine; Root Rot; Disease; T. harzianum

\section{Introduction}

Grapevine tree (Vitis spp.) subject attack by root rot and wilt diseases in Egypt and the world caused by dominant various soil borne pathogenic fungi of Fusarium spp., Rhizoctonia solani, Macrophomina phaseolina and Botryodiplodia theobromae, considerable losses of vegetative growth and yield productivity year after year in nurseries and field conditions [1-4].

Application of biocontrol agents i.e. B. subtilis, P. fluorescens and Streptomyces alni by soaking grapevine plant or soil drench before planted sowing under artificial infestation soil and natural infestation in open field were significantly reduced root rot incidence of grapevine plant, disease severity and significantly enhanced yield components of grapevine fruits as the results of reduction of fungal count in grapevine rhizosphere and their colonization in roots [1-3].

Endophytic microorganisms of fungi and bacteria can promote plant growth, yield and controlling plant diseases by improving multiple resistance actions [5-9]. Endophytic isolates of B. subti- lis were highly reduction root rot disease of peanut and increased seed yield [6]. Endophytic biocontrol agents of fungi such as Trichoderma spp. were parasitic and antifungal activity against Phytophthora capsici and induced resistance capabilities in hot pepper [7]. Penicillium simplicissimum, Leptosphaeria sp., Talaromyces flavus and Acremonium sp. isolated from cotton roots were significantly reduced wilt disease incidence of cotton caused by Verticillium dahliae [10]. Recently, Trichoderma asperellum which isolated from rhizosphere showed high ability for plant promotion growth and induce resistance of turmeric against rhizome rot caused by Pythium aphanidermatum by enhanced defense-related enzymes of peroxidase, phenylalanine amino lyase and polyphenol oxidase [11]. The antifungal activity of black seed due to thymoquinone (42.4\%), p-cymene (14.1\%), carvacrol (10.3\%), longifolene $(6.1 \%)$, 4-terpineol (5.1\%) [12]. Recently combination of biocontrol agents and chemicals a novel alternative plant diseases management approach for control of plant pathogens. A mixture of Bacillus subtilis, Trichoderma harzianum and nonpathogenic F. oxysporum was reported to suppressed wilt disease of chickpea of F. oxysporum f. sp. ciceris [5], 
combined treatment of $T$. viride + B. subtilis reduced root rot disease incidence of tomato caused by Fusarium solani [13], combined treatments of Trichoderma viride + VA mycorrhizae (VAM) followed by Bacillus subtilis + Trichoderma viride + VAM were the most effective mixtures in controlling wilt and root rot diseases of sesame [14], combination of T. harzianum and Pseudomonas fluorescence significantly reduced wilt of cucumber caused by Fusarium oxysporum f. sp. radices [15], chitosan combined with clove essential oil was used for controlling green mold of citrus [16]. Moreover, agar as natural extraction of algae was used for protection banana fruit diseases caused by fungi and extended fruits during marketing, transportation and storage [17]. Formulation included essential oil of Origanum vulgare and chitosan were control postharvest mold of cherry tomato fruit [18], peach fruit rot [19] and enhanced quality and shelf life. This investigation aimed to integrated control of root rot of grapevine by combination of biocontrol agents and safe chemical as fungicides alternatives.

\section{Materials and Methods}

Grapevine root rot pathogens

Pathogenic fungal isolates causing root rot disease of grapevine i.e. Fusarium oxysporum, Fusarium solani, Fusarium avenacum, Botryodiplodia theobromae and endophytic isolates of Trichoderma spp. and bacteria spp. were kindly provided from Plant Pathology Department, National Research Centre, Egypt

\section{Organic, antioxidants acids and essential oils}

Fresh stock of black seed and lemon essential oils provided from El Kapten company, Egypt. Meanwhile, propionic acid, salicylic acid and sorbic acid were provided from El Ghamhoreia Company, Cairo, Egypt.

Antagonistic potential of endophytic microorganisms against casual pathogens

Antagonistic ability of different endophytic microorganisms isolates were evaluated on dul culture (PDA) medium plates against fungal causal root rot of grapevine. Plates were inoculated with central 5-mm disk of mycelial growth 7 days old on PDA medium of each pathogenic fungal isolates. Two $5 \mathrm{~mm}$ disks of endophytic fungal growth culture or two streak of each endophytic bacteria tested were placed onto PDA, at two edge opposite each pathogenic fungi. Five plates were used as a replicates. Five plates were inoculated only with a central disk of each pathogenic fungi were served as a control. Petri dishes were incubated at $25 \pm 2^{\circ} \mathrm{C}$ for 5 days. Mycelial linear growth was recorded and conidia spores count $/ \mathrm{cm}^{2}$ using haemocytometer slide of each treatment. Inhibition zon free fungal mycelial growth was calculated as a percentage mycelial linear growth reduction compared with the control. Inhibition zone was calculated using formula as follows:

Reduction in linear growth \% $=\frac{\mathrm{R} 1-\mathrm{R} 2}{\mathrm{R} 1} \mathrm{X} 100$

Where: $\mathrm{R} 1=$ the radius of control growth, $\mathrm{R} 2=$ the radius of inhibited growth.
Compatibility of organic acids and essential oils on endophytic biocontrol agents

Several promising organic and antioxidants acids showed highly effect against mycelial growth and conidia sporulation of fungi causing root rot disease of grapevine i.e. propionic acid, sorbic acid and salicylic acid at $(0.1 \%)$ as well as two essential oils i.e. black seed oil and lemon oil at (4\%). In this manner, these a biotic agents were individually and in combination at half rates were tested also against growth of endophytic biocontrol agents Trichoderma harzianum and Bacillus subtilis. Each abiotic agents was mixed gently in Conical flasks containing sterilized PDA medium and dispensed in sterilized Petri dishes (9-cm-diameter). Each Petri plate after solidification was inoculated by central equal disk (5-mm) of T. harzianum isolate. Five plates were used as a replicates and five plates were served as a control. Plates were incubated for five days at 25 $\pm 2^{\circ} \mathrm{C}$. The average of mycelial linear growth of $T$. harzianum isolate was measured and reduction percentage of fungal growth was calculated compare the control as well as average number of conidial spores count $/ \mathrm{cm}^{2}$. Meanwhile, for endophytic bacterial isolates, sterilized Conical flask of nutrients agar medium were inoculated individually by bacterial isolate then dispensed in sterilized Petri dishes (9-cm-diameter). Four disks of sterilized filter paper ( $5 \mathrm{~mm}$ ) were saturated by each different materials by dipped for one minute in suspensions then putted on the surface of inoculated nutrient agar medium with isolate of Bacillus subtilis. Inhibition of bacterial growth and inhibition zone $(\mathrm{mm})$ were determined according to adopted growth scale as following: $+++=$ very good growth, $++=$ moderate growth, $+=$ low growth, $-=$ non growth .

\section{Management of root rot of grapevine}

Pot experiment was carried out in greenhouse of Plant Pathology Department, National Research Centre, Cairo, Egypt. Sterilized plastic pots $25-\mathrm{cm}$ in diameter were filled with sterilized loam sandy soil was infested with mixture of homogenized of four fungi inocula ratio $1: 1: 1: 1$ by the rate $2.5 \%(\mathrm{w} / \mathrm{w})$. Fresh aqueous emulsion of black seed essential oil was prepared at $4 \%$ concentration by supply with two $\mathrm{ml}$ of Tween-80 (0.2\%). Aqueous emulsion of propionic or sorbic acids $(0.1 \% \mathrm{w} / \mathrm{v})$ were prepared by dissolving in sterilized distilled water supply with two ml of Tween-80 (0.2\%). Spore suspension $1 \times 10^{8} / \mathrm{ml}$. Inoculum of T. harzianum prepared on PDA broth culture incubated at $28^{\circ} \mathrm{C}$ for 10 days. Meanwhile, inoculum of $B$. subtilis obtained from culture growth for 48 hours in nutrient broth medium, cells harvested by centrifugation, resuspended in sterile distilled water and adjusted to $3 \times 10^{6} \mathrm{cell} / \mathrm{ml}$. Infested pots received $500 \mathrm{ml}$ of each individual or in combinations of biotic and abiotic agents. Grapevine Cv. Crimson transplanting one year old was cultivated in each pot. Five pots were used as a replicates for each treatment and five pots were served as a control. Percentage of root rot disease incidence and disease severity were recorded 3 months after cultivation grape plants. Disease severity was determined as follows:

Disease severity $=\Sigma(\mathrm{n} \times \mathrm{r}) \times 100 / \mathrm{N}$.

Where: $\mathrm{n}=$ Number of plant in each numerical disease grade; $\mathrm{r}$ $=$ Number of the disease grade and $\mathrm{N}=$ Total number of plant mul- 
tiplied by the maximum numerical disease grade on shoot and root system of grapevine plants.

Disease severity on shoot was determined using linear scale from 0 to 4 as follows: $0=$ healthy, $1=$ yellowish $+1 / 3$ plant wilted, $2=2 / 3$ plant wilted, $3=$ whole plant wilted, $4=$ plants dead showed sever wilt. Disease severity of root rot on root was determined using linear scale from 0 to 3 as follows: $0=$ normal color (health), $1=$ slight brown discoloration cover $25 \%$ of root system, $2=$ moderate brown discoloration cover $50 \%$ of root system, $3=$ dark brown discoloration cover $75 \%$ of root system. Morphological characters of grapevine plants i.e. plant height, root length (cm), fresh and dry weight ( $\mathrm{g}$ ) of shoot and root and root size $\left(\mathrm{cm}^{3}\right)$ were determined at the experimental end three months after cultivation.

\section{Statistical analysis}

All data were subjected to one-way ANOVA followed by independent t-test at $\mathrm{P} \leq 0.05$ using SPSS 17 software (SPSS Inc).

\section{Results}

Antagonism of endophytic microorganisms against fungi causing root rot of grapevine

Nine isolates of endophytic fungi and bacteria were significantly reduced mycelial linear growth and conidial sporulation of fungal pathogens isolates tested compare than in the control. B. subtilis isolate was the best endophytic significantly reduced mycelial linear growth followed by T. harzianum was completely inhibited $(100 \%)$ conidial sporulation of fungi followed by B. subtilis. Data in table 1 and figure 1 revealed that $B$. subtilis isolate was the best endophytic microorganisms and significantly reduced mycelial linear growth (88.9\%) of Fusarium oxysporum followed by T. harzianum $(82.2 \%)$ and B. megatherium (75.6\%). In addition, T. harzianum was completely inhibited (100\%) conidial sporulation of Fusarium oxysporum followed by B. subtilis. Furthermore, as shown in figure 1 B. subtilis recorded highly clear zone inhibition of mycelial linear growth of Fusarium oxysporum followed by Bacillus brives. Also, as shown in table 1 B. polymexa, B. megatherium and T. viride (No. 3) recorded high reduction of mycelial linear growth and conidial sporulation of Fusarium oxysporum compare the control. On the other hand, Pseudomonas fluorescens followed by T. viride isolates (No. 1) and (No. 2) were the lowest endophytic microorganism's reduced mycelial linear growth and conidial sporulation of $\mathrm{Fu}$ sarium oxysporum. Furthermore, as shown in figure 1 Trichoderma harzianum only was growing over culture of Fusarium oxysporum. In addition, data in table 2 and figure 1. Trichoderma harzianum was the best endophytic microorganisms isolate and significantly reduced mycelial linear growth $(88.9 \%)$ of Fusarium avenacum and completely inhibited (100\%) conidial sporulation followed by B. subtilis isolate was significantly reduced mycelial linear growth $(77.8 \%)$ and recorded the largest clear inhibition zone toward mycelial linear growth of Fusarium avenacum as well as significantly reduced conidial sporulation followed by B. polymexa. In addition, as shown in figure 2 Trichoderma harzianum only than other isolates was grow over culture of Fusarium avenacum. On the other hand, B. megatherium and Pseudomonas fluorescens were recorded the lowest reduction of mycelial linear growth and conidial sporulation of Fusarium avenacum. Also, data in table 3 and figure 1 indicated that endophytic isolates B. megatherium and B. subtilis followed by T. harzianum were significantly reduced mycelial linear growth of Fusarium solani by the rate (85.6, 85.6 and 81.1\%) respectively. Meanwhile, as shown in figure 1 Pseudomonas fluorescens followed by $B$. brives were recorded the largest inhibition zone (15 and $12 \mathrm{~mm}$ ) on mycelial growth of Fusarium solani. In addition, T. harzianum was the best and significantly endophytic isolates which completely inhibited $(100 \%)$ conidial sporulation of Fusarium solani. Meanwhile, another endophytic isolates were also significantly reduced conidial sporulation of Fusarium solani compare than in the control. Furthermore, Trichoderma harzianum only than other isolates was grow over culture of Fusarium solani. In addition, Data in table 4 and figure 1 reported that Trichoderma harzianum was the best endophytic microorganisms isolate and significantly reduced mycelial linear growth $(75.6 \%)$ of Botryodiplodia theobromae and completely inhibited $(100 \%)$ conidial sporulation followed by B. subtilis isolate was significantly reduced mycelial linear growth (73.3\%) and conidial sporulation (92.4\%). Meanwhile, B. subtilis followed by B. polymexa were recorded the largest inhibition zone mycelial growth of Botryodiplodia theobromae. Furthermore, Trichoderma harzianum only than other isolates was grow over culture of Botryodiplodia theobromae.

\begin{tabular}{|l|c|c|c|c|}
\hline $\begin{array}{c}\text { Endophytic } \\
\text { microorganisms }\end{array}$ & $\begin{array}{c}\text { Linear } \\
\text { growth } \\
\text { (mm) }\end{array}$ & $\begin{array}{c}\text { Reduction } \\
\mathbf{( \% )}\end{array}$ & $\begin{array}{c}\text { Inhibition } \\
\text { zone } \mathbf{( m m )}\end{array}$ & $\begin{array}{c}\text { Conidia } \\
\mathbf{x 1 0}^{5} \mathbf{)} / \mathbf{c m}^{2}\end{array}$ \\
\hline $\begin{array}{l}\text { Trichoderma } \\
\text { viride } 1\end{array}$ & $33.0 \mathrm{~b}$ & 63.3 & 0.0 & $2.1 \mathrm{c}$ \\
\hline $\begin{array}{l}\text { Trichoderma } \\
\text { viride 2 }\end{array}$ & $29.0 \mathrm{c}$ & 67.8 & 0.0 & $2.9 \mathrm{~b}$ \\
\hline $\begin{array}{l}\text { Trichoderma } \\
\text { viride 3 }\end{array}$ & $26.0 \mathrm{~d}$ & 71.1 & 0.0 & $1.9 \mathrm{~d}$ \\
\hline $\begin{array}{l}\text { Trichoderma } \\
\text { harzianum }\end{array}$ & $16.0 \mathrm{~g}$ & 82.2 & $\begin{array}{c}0 \mathrm{ver} \\
\text { growth }\end{array}$ & $0.0 \mathrm{i}$ \\
\hline $\begin{array}{l}\text { Bacillus brives } \\
\text { Bacillus subtilis }\end{array}$ & $32.0 \mathrm{~cd}$ & 64.4 & 8.0 & $1.6 \mathrm{f}$ \\
\hline $\begin{array}{l}\text { Bacillus } \\
\text { polymoxa }\end{array}$ & $22.0 \mathrm{e}$ & 78.9 & 4.0 & $1.5 \mathrm{f}$ \\
\hline $\begin{array}{l}\text { Bacillus } \\
\text { megaterium }\end{array}$ & $19.0 \mathrm{f}$ & 75.6 & 5.0 & $1.1 \mathrm{~g}$ \\
\hline $\begin{array}{l}\text { Pseudomonas } \\
\text { fluorescens }\end{array}$ & $37.0 \mathrm{~b}$ & 58.9 & 4.0 & $1.7 \mathrm{e}$ \\
\hline Control & $90.0 \mathrm{a}$ & 0.0 & 0.0 & $23.6 \mathrm{a}$ \\
\hline
\end{tabular}

Table 1: Antagonism of endophytic microorganisms against Fusarium oxysporum.

Values within each column followed by the same letter are not significantly different $(\mathrm{P} \leq 0.05)$ according to Duncan's multiple range test.

Effect of organic and antioxidants acids, essential oils on growth of endophytic biocontrol agents

Several organic and antioxidants acids i.e. propionic, sorbic and salicylic acids at $0.1 \%$ as well as two essential oils i.e. black seed oil and lemon oil at $4 \%$ and combination between propionic + sorbic + black seed oil at $(0.05+0.05+2 \%$ respectively $)$ were tested against mycelial growth of endophytic biocontrol agents. Data in 

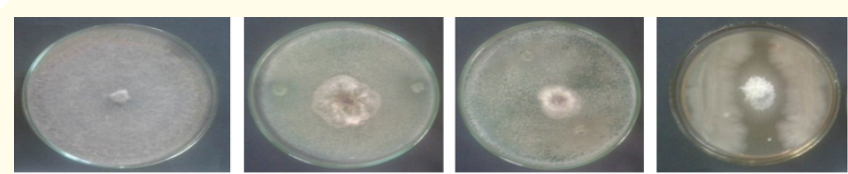

F. oxysporum
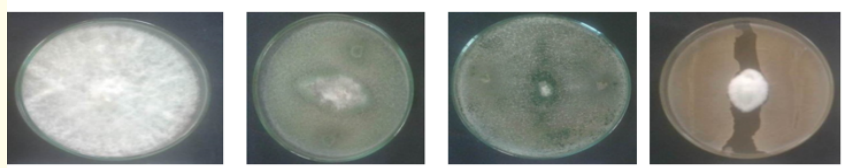

F. avenacum
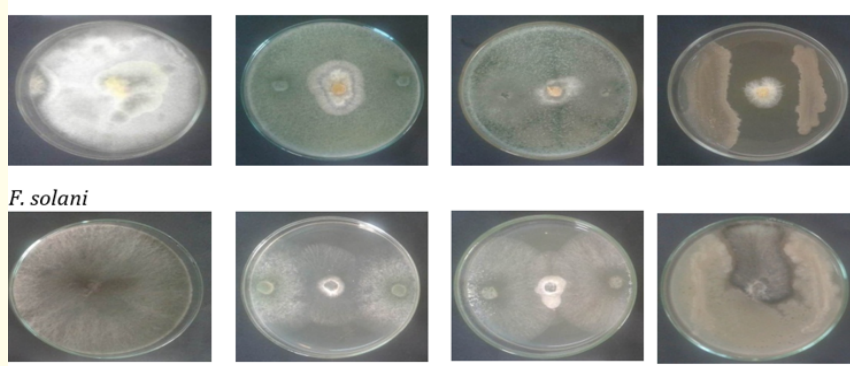

B. theobromae

T.viride

T. harzianum

B. subtilis

Figure 1: Antagonism of endophytic microorganisms against fungi causing root rot of grapevine.

\begin{tabular}{|c|c|c|c|c|}
\hline $\begin{array}{c}\text { Endophytic } \\
\text { microorganisms }\end{array}$ & $\begin{array}{c}\text { L. growth } \\
\text { (mm) }\end{array}$ & $\begin{array}{c}\text { Reduction } \\
(\%)\end{array}$ & $\begin{array}{l}\text { Inhibition } \\
\text { zone (mm) }\end{array}$ & $\begin{array}{l}\text { Conidia } x \\
\left.10^{5}\right) / \mathrm{cm}^{2}\end{array}$ \\
\hline $\begin{array}{l}\text { Trichoderma viride } \\
1\end{array}$ & $32.0 \mathrm{c}$ & 64.4 & 0.0 & $1.9 \mathrm{e}$ \\
\hline $\begin{array}{l}\text { Trichoderma viride } \\
2\end{array}$ & $20.0 \mathrm{e}$ & 77.8 & 0.0 & $2.6 \mathrm{~b}$ \\
\hline $\begin{array}{l}\text { Trichoderma viride } \\
3\end{array}$ & $29.0 \mathrm{~cd}$ & 67.8 & 0.0 & $2.1 \mathrm{~d}$ \\
\hline $\begin{array}{l}\text { Trichoderma har- } \\
\text { zianum }\end{array}$ & $10.0 \mathrm{f}$ & 88.9 & $\begin{array}{l}\text { Over } \\
\text { growth }\end{array}$ & $0.0 \mathrm{i}$ \\
\hline Bacillus brives & $28.0 \mathrm{~d}$ & 68.9 & 4.0 & $1.6 \mathrm{f}$ \\
\hline Bacillus subtilis & $20.0 \mathrm{e}$ & 77.8 & 13.0 & $1.2 \mathrm{~g}$ \\
\hline Bacillus polymoxa & $20.0 \mathrm{e}$ & 77.8 & 6.0 & $1.5 \mathrm{~h}$ \\
\hline \begin{tabular}{|l} 
Bacillus \\
megaterium
\end{tabular} & $41.0 \mathrm{~b}$ & 54.4 & 5.0 & $2.6 \mathrm{~b}$ \\
\hline $\begin{array}{l}\text { Pseudomonas } \\
\text { fluorescens }\end{array}$ & $40.0 \mathrm{~b}$ & 55.6 & 5.0 & $2.2 \mathrm{c}$ \\
\hline Control & $90.0 \mathrm{a}$ & 0.0 & 0.0 & $22.7 \mathrm{a}$ \\
\hline
\end{tabular}

Table 2: Antagonism of endophytic microorganisms against Fusarium avenacum.

Values within each column followed by the same letter are not significantly different $(\mathrm{P} \leq 0.05)$ according to Duncan's multiple range test.

table 5 showed that all organic and antioxidants acids tested at $(0.1 \%)$, essential oils at $(4 \%)$ and the combination of propionic acid at $(0.05 \%)$, sorbic acid at $(0.05 \%)$ and black seed oil at (2\%) were significantly inhibited mycelial growth and conidial sporulation of Trichoderma harzianum compare than the control. Black seed oil highly and significantly reduced mycelial linear growth and conidial sporulation of Trichoderma harzianum followed by lemon oil then salicylic acid. On the other hand, sorbic acid at $(0.1 \%)$ was the lowest agent reduced mycelial linear growth and

\begin{tabular}{|c|c|c|c|c|}
\hline $\begin{array}{c}\text { Endophytic } \\
\text { microorganisms }\end{array}$ & $\begin{array}{l}\text { L. growth } \\
\text { (mm) }\end{array}$ & $\begin{array}{c}\text { Reduction } \\
(\%)\end{array}$ & $\begin{array}{c}\text { Inhibition } \\
\text { zone (mm) }\end{array}$ & $\begin{array}{c}\text { Conidia } \\
(\text { No. } x \\
\left.10^{5}\right) / \mathbf{c m}^{2}\end{array}$ \\
\hline $\begin{array}{l}\text { Trichoderma } \\
\text { viride } 1\end{array}$ & $26.0 c$ & 71.0 & 0.0 & $1.9 \mathrm{~d}$ \\
\hline $\begin{array}{l}\text { Trichoderma } \\
\text { viride } 2\end{array}$ & $19.0 \mathrm{~d}$ & 78.9 & 0.0 & $2.8 \mathrm{~b}$ \\
\hline $\begin{array}{l}\text { Trichoderma } \\
\text { viride } 3\end{array}$ & $27.0 \mathrm{c}$ & 70.0 & 0.0 & $2.1 \mathrm{c}$ \\
\hline \begin{tabular}{|l}
$\begin{array}{l}\text { Trichoderma } \\
\text { harzianum }\end{array}$ \\
\end{tabular} & $17.0 \mathrm{~d}$ & 81.1 & $\begin{array}{l}\text { Over } \\
\text { growth }\end{array}$ & $0.0 \mathrm{e}$ \\
\hline Bacillus brives & $20.0 \mathrm{~d}$ & 77.8 & 12.0 & $2.2 \mathrm{c}$ \\
\hline Bacillus subtilis & $13.0 \mathrm{f}$ & 85.6 & 5.0 & $1.9 \mathrm{~d}$ \\
\hline Bacillus polymoxa & $18.0 \mathrm{de}$ & 80.0 & 5.0 & $2.7 \mathrm{~b}$ \\
\hline $\begin{array}{l}\text { Bacillus } \\
\text { megaterium }\end{array}$ & $15.0 \mathrm{e}$ & 85.6 & 7.0 & $1.9 \mathrm{~d}$ \\
\hline $\begin{array}{l}\text { Pseudomonas } \\
\text { fluorescens }\end{array}$ & $31.0 \mathrm{~b}$ & 65.6 & 15.0 & $2.1 \mathrm{c}$ \\
\hline Control & $90.0 \mathrm{a}$ & 00.0 & 0.0 & $21.9 a$ \\
\hline
\end{tabular}

Table 3: Antagonism of endophytic microorganisms against Fusarium solani

Values within each column followed by the same letter are not significantly different $(\mathrm{P} \leq 0.05)$ according to Duncan's multiple range test.

\begin{tabular}{|l|c|c|c|c|}
\hline $\begin{array}{c}\text { Endophytic } \\
\text { microorganisms }\end{array}$ & $\begin{array}{c}\text { L. growth } \\
\mathbf{( m m )}\end{array}$ & $\begin{array}{c}\text { Reduction } \\
\mathbf{( \% )}\end{array}$ & $\begin{array}{c}\text { Inhibition } \\
\text { zone (mm) }\end{array}$ & $\begin{array}{c}\text { Conidia } \\
\text { (No. } \mathbf{x} \mathbf{1 0}^{5} \mathbf{)} \\
\mathbf{c m}^{\mathbf{2}}\end{array}$ \\
\hline $\begin{array}{l}\text { Trichoderma } \\
\text { viride 1 }\end{array}$ & $46.0 \mathrm{~b}$ & 48.9 & 0.0 & $2.2 \mathrm{f}$ \\
\hline $\begin{array}{l}\text { Trichoderma } \\
\text { viride 2 }\end{array}$ & $35.0 \mathrm{~d}$ & 61.1 & 0.0 & $3.1 \mathrm{~b}$ \\
\hline $\begin{array}{l}\text { Trichoderma } \\
\text { viride 3 }\end{array}$ & $41.0 \mathrm{c}$ & 54.4 & 0.0 & $2.7 \mathrm{c}$ \\
\hline $\begin{array}{l}\text { Trichoderma } \\
\text { harzianum }\end{array}$ & $22.0 \mathrm{e}$ & 75.6 & $0 \mathrm{ver}$ & $0.0 \mathrm{~g}$ \\
\hline $\begin{array}{l}\text { Bacillus brives } \\
\text { growth }\end{array}$ & $32.0 \mathrm{~d}$ & 64.0 & 3.0 & $2.3 \mathrm{f}$ \\
\hline Bacillus subtilis & $24.0 \mathrm{e}$ & 73.3 & 35.0 & $2.1 \mathrm{f}$ \\
\hline $\begin{array}{l}\text { Bacillus poly- } \\
\text { moxa }\end{array}$ & $35.0 \mathrm{~d}$ & 61.1 & 35.0 & $2.2 \mathrm{f}$ \\
\hline $\begin{array}{l}\text { Bacillus megate- } \\
\text { rium }\end{array}$ & $41.0 \mathrm{c}$ & 54.4 & 3.0 & $2.6 \mathrm{c}$ \\
\hline $\begin{array}{l}\text { Pseudomonas } \\
\text { fluorescens }\end{array}$ & $44.0 \mathrm{~b}$ & 51.1 & 3.0 & $2.5 \mathrm{de}$ \\
\hline Control & $90.0 \mathrm{a}$ & 00.0 & 0.0 & $27.8 \mathrm{a}$ \\
\hline
\end{tabular}

Table 4: Antagonism of endophytic microorganisms against Botryodiplodia theobromae.

Values within each column followed by the same letter are not significantly different $(\mathrm{P} \leq 0.05)$ according to Duncan's multiple range test.

conidial sporulation of Trichoderma harzianum followed by propionic acid at $(0.1 \%)$ then formula of propionic acid + sorbic acid + black seed oil at $(0.05 \%+0.05 \%+2.0 \%)$ respectively. Data in table 6 showed that the salicylic acid at $(0.1 \%)$ and lemon oil at $(4 \%)$ 


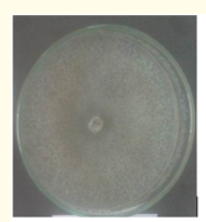

T. harzianum

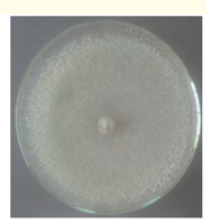

Propionic acid

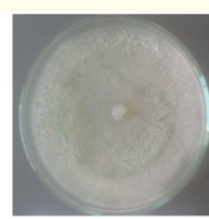

Sorbic acid

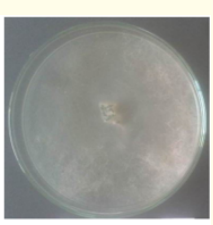

Black seed oil
Figure 2: Effect of organic acids, essential oils and their combinations on linear growth of T. harzianum.

\begin{tabular}{|c|c|c|c|c|c|}
\hline \multirow[b]{2}{*}{ Treatments } & \multirow{2}{*}{$\begin{array}{l}\text { Conc. } \\
(\%)\end{array}$} & \multicolumn{2}{|c|}{ Mycelial growth } & \multicolumn{2}{|c|}{ Conidial sporulation } \\
\hline & & $\begin{array}{l}\text { L. growth } \\
\text { (mm) }\end{array}$ & $\begin{array}{c}\text { Reduc- } \\
\text { tion (\%) }\end{array}$ & $\left(\begin{array}{c}\left(\text { No. } \mathbf{x 1 0} 0^{5}\right) / \\
\mathbf{c m}^{2}\end{array}\right.$ & $\begin{array}{c}\text { Reduction } \\
\text { (\%) }\end{array}$ \\
\hline $\begin{array}{c}\text { Sorbic acid } \\
\text { (SOA) }\end{array}$ & 0.1 & $77.0 \mathrm{~b}$ & 14.4 & $19.6 \mathrm{~b}$ & 19.0 \\
\hline $\begin{array}{l}\text { Propionic } \\
\text { acid (PPA) }\end{array}$ & 0.1 & $75.0 \mathrm{~b}$ & 16.7 & $18.3 \mathrm{~b}$ & 24.4 \\
\hline \begin{tabular}{|c} 
Salicylic acid \\
(SA)
\end{tabular} & 0.1 & $70.0 \mathrm{~b}$ & 22.2 & $16.8 \mathrm{c}$ & 30.6 \\
\hline $\begin{array}{l}\text { Black seed } \\
\text { oil (BSO) }\end{array}$ & 4 & $39.0 \mathrm{~d}$ & 56.7 & $5.6 \mathrm{~d}$ & 76.8 \\
\hline $\begin{array}{l}\text { Lemon oil } \\
\text { (LO) }\end{array}$ & 4 & $65.0 \mathrm{~d}$ & 27.8 & $8.2 \mathrm{~d}$ & 66.0 \\
\hline $\begin{array}{l}\text { SOA + PPA } \\
+ \text { BSO }\end{array}$ & $\begin{array}{c}0.05+ \\
0.05 \\
+2\end{array}$ & $72.0 \mathrm{~b}$ & 20.0 & $15.4 \mathrm{c}$ & 36.3 \\
\hline Control & 0.0 & $90.0 \mathrm{a}$ & 00.0 & $24.2 \mathrm{a}$ & 00.0 \\
\hline
\end{tabular}

Table 5: Effect of organic and antioxidants acids, essential oils and their combination on growth of T. harzianum.

Values within each column followed by the same letter are not significantly different $(\mathrm{P} \leq 0.05)$ according to Duncan's multiple range test.

\begin{tabular}{|l|c|c|c|}
\hline \multirow{2}{*}{ Treatments } & Conc. (\%) & \multicolumn{2}{|c|}{ Bacillus subtilis } \\
\cline { 3 - 4 } & & Growth & Inhibition zone (mm) \\
\hline Sorbic acid (SOA) & 0.1 & +++ & 0.0 \\
\hline $\begin{array}{l}\text { Propionic acid } \\
\text { (PPA) }\end{array}$ & 0.1 & +++ & 0.0 \\
\hline Salicylic acid (SA) & 0.1 & ++ & 2.0 \\
\hline Black seed oil (BSO) & 4.0 & +++ & 0.0 \\
\hline Lemon oil (LO) & 4.0 & ++ & 3.0 \\
\hline SOA + PPA + BSO & $\begin{array}{c}0.05+ \\
0.05+2.0\end{array}$ & +++ & 0.0 \\
\hline Control & 0.0 & +++ & 0.0 \\
\hline
\end{tabular}

Table 6: Effect of organic acids, essential oils and their combination on growth of $B$. subtilis.

+++: Very Good Growth; ++: Middle Growth; +: Low Growth.

were significantly inhibited growth of $B$. subtilis meanwhile, propionic and sorbic acids at $(0.1 \%)$, essential oils at $(4 \%)$ and their combination formula of propionic acid $(0.05)+$ sorbic acid (0.05) + black seed oil at (2.0) were not inhibited growth of B. subtilis like its in the untreated (control). So, this formula of the most promising and compatible in combination of biocontrol agents of Trichoderma harzianum or B. subtilis for management root rot disease.
Integrated control of root rot disease and their effect on morphological characters of grapevine plants

The most promising antagonistic candidates tested before of endophytic bacteria and fungal isolates against root rot causal organisms as well as organic and antioxidants acids i.e. propionic and sorbic acids, essential oil i.e. black seed oil, bio control agents $T$. harzianum and B. subtilis and their combinations were used as soil drench at cultivation time for controlling root rot of grapevine under artificial soil infested with pathogens. Data in table 7 show that all different treatments soil drench with each propionic, sorbic acids, black seed oil, endophytic biocontrol agents of T. harzianum, $B$. subtilis and their combinations were significantly reduced percentage of root rot disease on grapevine plants and disease severity on shoot and root system than the control. Soil drench with mixture of propionic acid + sorbic acid and propionic acid + sorbic acid $+T$. harzianum + B. subtilis were the best and significantly treatments than all another treatments its completely inhibited (100\%) of root rot incidence of grapevine plants. Also, data in table 7 indicated that soil drench with T. harzianum alone or in combination with B. subtilis recorded high and significantly reduction of root rot incidence of grapevine plants. In addition, propionic acid alone was reduced percentage of root rot disease on grapevine plants $80 \%$ with high significances for reduced disease severity of shoot and root followed by combined treatments i.e. propionic acid + sorbic acid $+T$. harzianum, propionic acid + sorbic acid + black seed oil and propionic acid + sorbic acid + black seed oil + B. subtilis followed by sorbic acid alone and propionic acid + sorbic acid $+B$. subtilis. On the other hand, the lowest treatment reduced root rot percentage (70\%) and disease severity of shoot (1.4) and root (1.0) of grapevine plants were black seed oil and B. subtilis. Regarding to previous treatments, morphological characters of grapevine plants were determined at the end of experiment 3 months after cultivation. Data recorded in table 8 indicated that all different treatments were significantly increased all morphological characters tested i.e. length of grapevine plants shoot and root, fresh and dry weight of shoot and root as well as root size than in the control. Data in table 8 show that treatment with propionic acid + sorbic acid was the best and significantly increased shoot length, fresh weight of shoot and root size of grapevine plants. Meanwhile propionic acid treatment found the superior and significantly for increase length of grapevine plant root followed by propionic acid + sorbic acid treatment. Propionic acid + sorbic acid treatment recorded high value of shoot length followed by propionic acid + sorbic acid + T. harzianum, propionic acid + sorbic acid + black seed oil and T. harzianum. Also, data in table 8 indicated that propionic acid + sorbic acid $+T$. harzianum + B. subtilis were the superior treatment recorded high value of fresh weight of root followed by propionic acid + sorbic acid + B. subtilis and T. harzianum + B. subtilis. In addition, as shown in table 8 high value of shoot dry weight were recorded with propionic acid + sorbic acid + B. subtilis and T. harzianum followed by propionic acid + sorbic acid treatments. On the other hand, the lowest values of most morphological characters of grapevine plants were recorded with black seed oil treatment followed by B. subtilis. In general, the best and significantly treatments were increased most morphological characters of grapevine plants were propionic 


\begin{tabular}{|l|c|c|c|}
\hline \multirow{2}{*}{\multicolumn{1}{|c|}{ Treatments }} & \multicolumn{3}{|c|}{$\begin{array}{c}\text { Root rot disease incidence on } \\
\text { grapevine plant }\end{array}$} \\
\cline { 2 - 4 } & $\begin{array}{c}\text { Diseased } \\
\text { plant \% }\end{array}$ & \multicolumn{2}{|c|}{ Disease severity } \\
\cline { 2 - 4 } & $20.0 \mathrm{bc}$ & $0.4 \mathrm{e}$ & $0.4 \mathrm{~d}$ \\
\hline Propionic acid (PPA) & $20.0 \mathrm{bc}$ & $1.0 \mathrm{c}$ & $0.6 \mathrm{~cd}$ \\
\hline Sorbic acid (SOA) & $30.0 \mathrm{~b}$ & $1.4 \mathrm{~b}$ & $1.2 \mathrm{~b}$ \\
\hline Black seed oil (BSO) & $10.0 \mathrm{~cd}$ & $0.6 \mathrm{de}$ & $0.4 \mathrm{~d}$ \\
\hline $\begin{array}{l}\text { Trichoderma harzia- } \\
\text { num } \text { (Th) }\end{array}$ & & & \\
\hline Bacillus subtilis (Bs) & $30.0 \mathrm{~b}$ & $1.4 \mathrm{~b}$ & $1.2 \mathrm{~b}$ \\
\hline Propionic+ sorbic acids & $0.0 \mathrm{~d}$ & $0.0 \mathrm{f}$ & $0.0 \mathrm{e}$ \\
\hline Th+B. subtilis & $10.0 \mathrm{~cd}$ & $0.4 \mathrm{e}$ & $0.4 \mathrm{~d}$ \\
\hline PPA + SOA + (BSO) & $20.0 \mathrm{bc}$ & $0.8 \mathrm{~cd}$ & $0.6 \mathrm{~cd}$ \\
\hline PPA + SOA+ Th & $20.0 \mathrm{bc}$ & $0.8 \mathrm{~cd}$ & $0.6 \mathrm{~cd}$ \\
\hline PPA + SOA+Bs & $20.0 \mathrm{bc}$ & $1.0 \mathrm{c}$ & $0.8 \mathrm{c}$ \\
\hline PPA + SOA +Bs+ BSO & $20.0 \mathrm{bc}$ & $0.8 \mathrm{~cd}$ & $0.6 \mathrm{~cd}$ \\
\hline PPA + SOA+Th+ Bs & $0.0 \mathrm{~d}$ & $0.0 \mathrm{f}$ & $0.0 \mathrm{e}$ \\
\hline Control & $100.0 \mathrm{a}$ & $4.0 \mathrm{a}$ & $2.6 \mathrm{a}$ \\
\hline
\end{tabular}

Table 7: Effect of organic acids, essential oils, endophytic agents and their combinations on root rot incidence of grapevine.

Values within each column followed by the same letter are not significantly different $(\mathrm{P} \leq 0.05)$ according to Duncan's multiple range test.

- Disease severity of shoot was determined according to [29] as follows: $0=$ healthy, $1=$ yellowish $+1 / 3$ plant wilted, $2=2 / 3$ plant wilt ed, $3=$ whole plant wilted and $4=$ plants dead showed sever wilt.

\begin{tabular}{|c|c|c|c|c|c|c|c|}
\hline \multirow{3}{*}{ Treatments } & \multicolumn{7}{|c|}{ Morphological characters of grapevine plants } \\
\hline & \multicolumn{2}{|c|}{ Length $(\mathrm{cm})$} & \multicolumn{2}{|c|}{\begin{tabular}{|c|} 
Fresh \\
weight (g)
\end{tabular}} & \multicolumn{2}{|c|}{\begin{tabular}{|c|} 
Dry weight \\
(g)
\end{tabular}} & \multirow{2}{*}{$\begin{array}{c}\text { Root } \\
\text { size } \\
\left(\mathrm{cm}^{2}\right)\end{array}$} \\
\hline & Shoot & Root & Shoot & Root & Shoot & Root & \\
\hline $\begin{array}{l}\text { Propionic acid } \\
\text { (PPA) }\end{array}$ & $64.0 \mathrm{a}$ & $28.0 \mathrm{a}$ & $28.0 \mathrm{a}$ & $13.0 \mathrm{a}$ & $13.9 \mathrm{a}$ & $6.5 a$ & $17.0 \mathrm{a}$ \\
\hline \begin{tabular}{|l} 
Sorbic acid \\
(SOA)
\end{tabular} & $63.0 \mathrm{a}$ & $20.0 \mathrm{~b}$ & $25.0 \mathrm{a}$ & $11.5 \mathrm{a}$ & $12.6 \mathrm{a}$ & $6.4 \mathrm{a}$ & $19.0 \mathrm{a}$ \\
\hline $\begin{array}{l}\text { Black seed oil } \\
\text { (BSO) }\end{array}$ & $42.0 \mathrm{c}$ & $17.0 \mathrm{c}$ & $15.2 \mathrm{~b}$ & $11.5 \mathrm{a}$ & $7.3 \mathrm{~b}$ & $6.2 \mathrm{a}$ & $12.5 \mathrm{bc}$ \\
\hline $\begin{array}{l}\text { Trichoderma } \\
\text { harzianum } \\
\text { (Th) }\end{array}$ & $64.0 \mathrm{a}$ & $22.2 \mathrm{~b}$ & $27.8 \mathrm{a}$ & $12.2 \mathrm{a}$ & $14.6 \mathrm{a}$ & $6.5 \mathrm{a}$ & $17.0 \mathrm{a}$ \\
\hline \begin{tabular}{|l} 
Bacillus \\
subtilis (Bs)
\end{tabular} & $44.0 \mathrm{c}$ & $14.8 \mathrm{~d}$ & $15.6 \mathrm{~b}$ & $9.4 \mathrm{~b}$ & $6.5 b$ & $5.0 \mathrm{~b}$ & $10.0 \mathrm{c}$ \\
\hline \begin{tabular}{|l|}
$\begin{array}{l}\text { Propionic+ } \\
\text { sorbic acids }\end{array}$ \\
\end{tabular} & 65.0a & $23.0 \mathrm{~b}$ & $29.6 \mathrm{a}$ & $12.2 \mathrm{a}$ & $14.5 \mathrm{a}$ & $6.5 a$ & $20.0 \mathrm{a}$ \\
\hline Th +B. subtilis & 60.0a & $20.0 \mathrm{~b}$ & $26.0 \mathrm{a}$ & $13.0 \mathrm{a}$ & $13.2 \mathrm{a}$ & $6.2 \mathrm{a}$ & $19.0 \mathrm{a}$ \\
\hline $\begin{array}{l}\mathrm{PPA}+\mathrm{SOA}+ \\
(\mathrm{BSO})\end{array}$ & $64.0 \mathrm{a}$ & $20.0 \mathrm{~b}$ & $29.0 \mathrm{a}$ & $12.6 \mathrm{a}$ & $15.0 \mathrm{a}$ & $6.7 a$ & $16.5 \mathrm{a}$ \\
\hline $\mathrm{PPA}+\mathrm{SOA}+\mathrm{Th}$ & $64.0 \mathrm{a}$ & $20.5 \mathrm{~b}$ & $23.5 \mathrm{a}$ & $12.0 \mathrm{a}$ & $12.5 \mathrm{a}$ & $5.8 \mathrm{~b}$ & $14.0 \mathrm{~b}$ \\
\hline $\mathrm{PPA}+\mathrm{SOA}+\mathrm{Bs}$ & $59.0 \mathrm{a}$ & $20.0 \mathrm{~b}$ & $29.0 \mathrm{a}$ & $13.0 \mathrm{a}$ & $14.6 \mathrm{a}$ & $6.1 \mathrm{a}$ & $17.0 \mathrm{a}$ \\
\hline $\begin{array}{l}\mathrm{PPA}+\mathrm{SOA} \\
+\mathrm{Bs}+\mathrm{BSO} \\
\end{array}$ & $50.0 \mathrm{~b}$ & $17.6 \mathrm{c}$ & $27.2 \mathrm{a}$ & $12.0 \mathrm{a}$ & 13.0a & $6.0 \mathrm{a}$ & $15.0 \mathrm{a}$ \\
\hline $\begin{array}{l}\mathrm{PPA}+ \\
\mathrm{SOA}+\mathrm{Th}+\mathrm{Bs}\end{array}$ & $60.0 \mathrm{a}$ & $19.5 \mathrm{~b}$ & $26.5 \mathrm{a}$ & $13.4 \mathrm{a}$ & $13.7 \mathrm{a}$ & $6.3 a$ & $20.0 \mathrm{a}$ \\
\hline Control & $31.0 \mathrm{~d}$ & $11.0 \mathrm{e}$ & $10.0 \mathrm{c}$ & $5.4 \mathrm{c}$ & $4.3 \mathrm{c}$ & $2.4 \mathrm{c}$ & $6.0 \mathrm{e}$ \\
\hline
\end{tabular}

Table 8: Effect of organic and antioxidants acids, essential oils, endophytic biocontrol agents and their combinations on morphological characters of grapevine plants under artificial infestation by causal pathogens.

Values within each column followed by the same letter are not significantly different $(\mathrm{P} \leq 0.05)$ according to Duncan's multiple range test. acid + sorbic acid treatment followed by propionic acid + sorbic acid + B. subtilis then propionic acid + sorbic acid + black seed oil.

\section{Discussion and Conclusion}

The integration of compatible between biocontrol agents, safety organic acids and natural extracts more effective against phytopathogens growth, sporulations, pathological action and their resistance pesticides for reduce pesticides application [20,21]. In this study, four isolates endophytic fungi of T. viride and T. harzianum as well five isolates of bacteria i.e. Bacillus subtilis, B. brives, B. polymexa, B. megatherium and Pseudomonas fluorescens tested their antagonistic potential against mycelial growth and conidial sporulation of highly aggressive fungal isolates causing root rot disease of grapevine. All endophytic isolates were significantly reduced mycelial linear growth and conidial sporulation of the four fungal isolates compare than in the control. Two endophytic isolates of Trichoderma harzianum and Bacillus subtilis were significantly reduced mycelial linear growth and conidial sporulation of fungi tested as well as over lapping growth of T. harzianum on fungi tested. In addition, endophytic isolate of Bacillus subtilis recorded high zone inhibition toward all pathogenic fungi tested than another endophytic bacterial isolates in this study. These results have been confirmed by many investigators [7,22,23]. In this respect, biocontrol agents of bacterial isolates of Bacillus megaterium KU143 and Pseudomonas protegens AS15 against fungi of Aspergillus and Penicillium spp. during rice grain storage were producing volatiles components that significantly inhibited mycelial growth, sporulation, and conidial germination of the fungi as well fungal populations on rice grains. Theses antifungal compound, 5-methyl-2-phenyl-1H-indole, was produced by strain KU143 and the antimicrobial compounds, 2-butyl 1-octanal, dimethyl disulfide, 2-iso-propyl-5-methyl-1-heptanol and 4-trifluoroacetoxyhexadecane, were produced by strain AS15 [9]. In this investigation, no antagonistic interaction was observed between endophytic isolates of Trichoderma harzianum and Bacillus subtilis as a most promising endophytic biocontrol agents against fungi causing root rot of grapevine. In this study different combination between sorbic acid + propionic acid at $(0.2 \%)$ was the best treatment reduce root rot on grapevine plants followed by sorbic acid + propionic acid + black seed oil then propionic acid + black seed oil. Meanwhile, sorbic acid + black seed oil was the lowest effect. These results are agreement with results obtained by [18,24]. Moreover, most of promising essential oil, organic and antioxidants acids and their combination highly antifungal of fungi causing root rot of grapevine, biocontrol agents isolates of Trichoderma harzianum and $B a$ cillus subtilis were also studied. Sorbic acid, propionic acid, salicylic acid and black seed oil as well as the combination of sorbic acid + propionic acid + black seed oil were tested. Results obtained indicated that sorbic acid followed by propionic acid were the least effect on mycelial linear growth and conidial sporulation of Trichoderma harzianum. In addation, sorbic acid, propionic acid, black seed oil and their combination had no effect negatively on Bacillus subtilis growth. So, sorbic acid, propionic acid and black seed oil as individual agents and their combination were the most promising agent used in the combination with both endophytic biocontrol agents i.e. Trichoderma harzianum and Bacillus subtilis in the programs for controlling root rot disease on grapevine. These results 
are agreement with results obtained by $[18,24,25]$. The compatibility synergistic of isolate of Trichoderma viride as biocontrol agent with some essential oils of wintergreen and lemongrass [26]. Synergistic of Trichoderma asperellum and Coscinium fenestratum extract for controlling rice dirty panicle caused by Alternaria padwickii, Curvularia lunata, Fusarium incunatum and Bipolaris oryzae [27]. Under soil artificially infestation with pathogenic fungi soil application with promising essential oils (black seed oil), organic and antioxidants acids (propionic acid and sorbic acid) as well as endophytic biocontrol agents isolates of Trichoderma harzianum and Bacillus subtilis as individual and in combination significantly reduced root rot incidence of grapevine plants. The most application treatments were completely suppress root rot disease of grapevine plants i.e. (propionic acid + sorbic acid) followed by (propionic acid + sorbic acid + Trichoderma harzianum + Bacillus subtilis) and significantly enhanced most morphological criteria of grapevine plants. These results are agreement with $[13,28]$. The mode of action of application treatments were included significantly reduction of cell wall degrading enzymes of cellulase and pectinase activities and recorded, high activities of oxidative enzymes of polyphenol oxidase (PPO) and peroxidase (PO) as well as chitinase enzyme. Propionic acid + sorbic acid followed by propionic acid + sorbic acid + Trichoderma harzianum + Bacillus subtilis were the most and significantly treatments suppress cellulase and pectinase activities, as well recorded high activities of polyphenol oxidase (PPO), peroxidase (PO) and chitinase enzymes. These results are agreement with [1,14]. Recently, Trichoderma asperellum which isolated from rhizosphere showed high ability for plant promotion growth and induce resistance of turmeric against rhizome rot caused by Pythium aphanidermatum by enhanced defense-related enzymes of peroxidase, phenylalanine amino lyase and polyphenol oxidase [11]. So, this investigation reported that using safety chemicals of organic and antioxidants acids as well endophytic biocontrol agents as alternatives of fungicides for controlling root rot of grapevine plants.

\section{Bibliography}

1. ESH Ziedan., et al. "Biological control of grapevine root-rot by antagonistic microorganisms". African Journal of Mycology and Biotechnology 13 (2005): 19-36.

2. E Ziedan and R El-Mohamedy. "Application of Pseudomonas fluorescens for controlling root-rot disease of grapevine". Research Journal of Agriculture and Biological Sciences 4 (2008): 346-353.

3. ESH Ziedan., et al. "Streptomyces alni as a biocontrol agent to root-rot of grapevine and increasing their efficiency by biofertilizers inocula". Archives of Phytopathology and Plant Protection 43 (2010): 634-646.

4. K Hemida., et al. "Etiology of fungi associated with grapevine decline and their pathological potential". Arab Universities Journal of Agricultural Sciences 25 (2017): 355-365.
5. A Hervas., et al. "Effects of commercial and indigenous microorganisms on Fusarium wilt development in chickpea”. Biological Control 13 (1998): 166-176.

6. E Ziedan. "Manipulating endophytic bacteria for biological control to soil borne diseases of peanut". Journal of Applied Sciences Research 2 (2006): 497-502.

7. H Bae., et al. "Endophytic Trichoderma isolates from tropical environments delay disease onset and induce resistance against Phytophthora capsici in hot pepper using multiple mechanisms". Molecular Plant-Microbe Interactions 24 (2011): 336-351.

8. N Amin., et al. "Identification and In Vitro Screening of Fungal Endophytes Against Pathogen of Maize Leaf Blight, Helminthosporium maydis". In: International Seminar and The $21^{\text {th }}$ National Congress of Indonesia Phytopathological Society (2011).

9. M Mannaa and KD Kim. "Biocontrol activity of volatile-producing Bacillus megaterium and Pseudomonas protegens against Aspergillus and Penicillium spp. predominant in stored rice grains: study II". Mycobiology 46 (2018): 52-63.

10. Y Yuan., et al. "Potential of endophytic fungi isolated from cotton roots for biological control against Verticillium wilt disease". PLoS One 12 (2017): e0170557.

11. G Vinayarani., et al. "Induction of systemic resistance in turmeric by rhizospheric isolate Trichoderma asperellum against rhizome rot disease". Journal of Plant Pathology (2019): 1-16.

12. H Mahmoudvand., et al. "Evaluation of antifungal activities of the essential oil and various extracts of Nigella sativa and its main component, thymoquinone against pathogenic dermatophyte strains". Journal de Mycologie Medicale 24 (2014): e155e161.

13. EM Morsy., et al. "Efficiency of Trichoderma viride and Bacillus subtilis as biocontrol agents against Fusarium solani on tomato plants". Egyptian Journal of Phytopathology 37 (2009): 47-57.

14. ESH Ziedan., et al. "Application of mycorrhizae for controlling root diseases of sesame". Journal of Plant Protection Research 51 (2011): 355-361.

15. H Alizadeh., et al. "Induced systemic resistance in cucumber and Arabidopsis thaliana by the combination of Trichoderma harzianum Tr6 and Pseudomonas sp. Ps14". Biological Control 65 (2013): 14-23.

16. T Elmahdy., et al. " Effect of chitosan and clove oil on physical and chemical properties of red roomy grapes during cold storage a-effect of chitosan and clove oil on weight loss and decay percentages". Assiut Journal of Agricultural Sciences 49 (2018): 110-117. 
17. ESH Ziedanv. "Agar-agar a promising edible coating agent for management of postharvest diseases and improving banana fruit quality". Journal of Plant Protection Research 58 (2018).

18. TA Barreto., et al. "A chitosan coating containing essential oil from Origanum vulgare L. to control postharvest mold infections and keep the quality of cherry tomato fruit". Frontiers in Microbiology 7 (2016): 1724.

19. SA Alamri., et al. "Formulation of mint and thyme essential oils with Arabic gum and Tween to enhance their efficiency in the control of postharvest rots of peach fruit". Canadian Journal of Plant Pathology (2019): 1-14.

20. ESH Ziedan., et al. "First record of Fusarium vascular wilt on grapevine in Egypt". Archives of Phytopathology and Plant Protection 44 (2011): 1719-1727.

21. M Ravindra. "Compatibility of fungicides with Trichoderma viride against Fusarium wilt caused by Fusarium udum". International Journal of Agriculture Sciences ISSN (2018): 09753710.

22. S Suciatmih and I Hidayat T. "Isolasi, identifikasi dan evaluasi antagonisme terhadap Fusarium oxysporum f. sp. cubense (foc): secara In vitro dari jamur endofit tanaman pisang" Berita Biologi 13 (2014): 71-83.

23. X Zhang., et al. "Screening and characterization of endophytic Bacillus for biocontrol of grapevine downy mildew". Crop Protection 96 (2017): 173-179.

24. X Shao., et al. "Effect of postharvest application of chitosan combined with clove oil against citrus green mold". Postharvest Biology and Technology 99 (2015): 37-43.

25. R Saikia., et al. "Role of salicylic acid in systemic resistance induced by Pseudomonas fluorescens against Fusarium oxysporum f. sp. ciceri in chickpea". Microbiological Research 158 (2003): 203-213.

26. S Vanitha. "Developing new botanical formulation using plant oils and testing their physical stability and antifungal activity against Alternaria chlamydospore causing leaf blight in Solanum nigrum". Agricultural Science Research Journal 1 (2010): 385-390.

27. N Kaewsalong., et al. "Synergistic effects of combinations of novel strains of Trichoderma species and Coscinium fenestratum extract in controlling rice dirty panicle". Journal of Plant Pathology 101 (2019): 367-372.

28. A Muthukumar., et al. "Efficacy of endophytic Pseudomonas fluorescens (Trevisan): migula against chilli damping-off". Journal of Biopesticides 3 (2010): 105.
29. IE Ziedan., et al. "Application of data encryption standard to bitmap and JPEG images". In: Proceedings of the Twentieth National Radio Science Conference (NRSC'2003): (IEEE Cat. No. 03EX665): IEEE (2003): C16-C11.

\section{Assets from publication with us}

- Prompt Acknowledgement after receiving the article

- Thorough Double blinded peer review

- Rapid Publication

- Issue of Publication Certificate

- High visibility of your Published work

Website: www.actascientific.com/

Submit Article: www.actascientific.com/submission.php Email us: editor@actascientific.com

Contact us: +919182824667 